\title{
Ethics and collective identity building: Scandinavian semicommunication and the possibilities of Philippine ethics
}

\author{
Jeremiah Lasquety-Reyes ${ }^{1,2} \&$ Allen Alvarez ${ }^{3}$
}

${ }^{1}$ De Wulf-Mansion Centre for Ancient, Medieval and Renaissance Philosophy, KU Leuven, Belgium, jeremiah.reyes@hiw.kuleuven.be

${ }^{2}$ Department of Philosophy, University of the Philippines Diliman, jeremiah.reyes@up.edu.ph

${ }^{3}$ Centre for Applied Ethics, School of Population \& Public Health, University of British Columbia \& Programme for Applied Ethics, Norwegian University of Science and Technology, allen.alvarez@ntnu.no

DOI: http://dx.doi.org/10.5324/eip.v9i2.1866

(cc) BY

This is an open access article distributed under the terms of the Creative Commons Attribution 4.0 International License, which permits unrestricted use, distribution, and reproduction in any medium, provided the original author and source are credited.

How should national societies build legitimate and inclusive collective identities amidst prolific multiculturalism and linguistic diversity? We argue that cultural ownership of particular ways of framing ethics should be part of this collective identity building process. We should avoid unfair domination of minority cultural identities, but how do we do this when ethical discourses themselves tend to be shaped by particular dominant identities? We look into the case of the challenges that a particular multicultural society, the Philippines, faces in its ongoing collective identity building project on three levels: (1) ethnic and linguistic differences (e.g. differences between Tagalog, Cebuano, Maranao, etc.), (2) the historical layers of foreign culture (e.g. Islamic, Spanish, and American) that have each influenced these distinct cultural identities in different degrees, and (3) the apparent domination of Tagalog linguistic culture over others. Our answer to the question of legitimate and inclusive collective identity comes from an inter-linguistic dialogue that can be effected between cultures by harnessing similarities of ethical concepts, without compromising cultural differences. We present three different possible approaches under the following headings: (1) Pilipino ethics, (2) Filipino ethics and (3) Philippine ethics, each representing a particular stance to the dominant Tagalog linguistic culture. We argue for the third option, which is the most inclusive because of how it equalizes the status of all participating cultures in the dialogue. We also draw from the possibilities afforded by the phenomena of Scandinavian 
semicommunication (Haugen 1966) and what this practice offers in making collective identity building more inclusive.

Keywords: social ethics, collective identity, multiculturalism, Scandinavian semicommunication, receptive multilingualism, Philippines

\section{Introduction}

In this paper we reflect on issues related to collective identity building in multicultural societies with respect to linguistic diversity and the indigenous ethical concepts found in related languages. We explore the possibilities afforded by Scandinavian semicommunication or receptive multilingualism-where "interlocutors use their respective mother tongue when speaking to each other" (Zeevaert \& Thije 2007: 1; cf. Haugen 1966; Thije \& Zeevaert 2007) 1 -as a means of expanding the relationship between collective identity building and ethics research in the Philippines, which is a very multicultural society ${ }^{2}$. Collective identity building has been the goal of ethnically mixed groups of people who are divided by language, values and culture, but who are seeking to become one nation with one "collective" identity. To reach this goal of collective identity, one way among many includes establishing a common language or means of communication between all the language groups. There are many other means, all of which may be essential to achieving the goal, but this paper will focus on the language aspect of collective identity building. With this focus on language, we criticize the tendency to privilege one language over others, such as the use of the Tagalog language in the Philippines as the de facto national language, and propose more inclusive ways of intercommunication. Since dealing with linguistic differences itself is multi-faceted, we explore the case of building collective identity through ethics research on common values that can be found among the different ethnic groups in the Philippines. We focus in particular on the language used and explored in ethics research and propose that it need not be dominated by one language but should include other Philippine languages. Thus we propose the more linguistically inclusive language programme of Philippine ethics versus the prevailing Tagalog-dominated programme $e^{3}$ of Filipino ethics. We will not have the space to present arguments in favour of "Filipino ethics," nor is this necessary, since we simply use the term as a marker for Tagalog language dominance in ethics research. Philippine ethics is also simply a marker for approaches to ethics research that include the study of ethical concepts of other and all languages and using these languages as means to communicate between researchers and users of research in the Philippines. This will be explained in further detail below.

The Philippine situation is particularly challenging because of several geographical, linguistic, and historical factors. It is an archipelago with regional and linguistic groups separated from each other by natural barriers. Furthermore, these regional cultures were also affected in various degrees by foreign influences, most notably by Spanish and American influences in the central and northern regions of the country, and Islamic influence in the south. The Philippines only gained its national independence in $1946,{ }^{4}$ and in the latter half of the $20^{\text {th }}$ century there was a 
sustained quest for "a collective national identity," for which the government and academic sectors used different strategies.

Shared identities bind cultures into one nation, one society or one region, but alienating differences can undermine such unity. Communication mediates transactions between cultures, and this process relies on the effectiveness of languages and dialects used. As Einar Haugen (Haugen 1966: 280) observed:

Communication does not require the participants to have identical languages. Despite the growing loss of efficiency in the communication process as language codes deviate, it is often astonishing how great a difference speakers can overcome if the will to understand is there...There are related languages... whose speakers can communicate by using their own languages, given only a little good will. From the historical linguist's point of view, these may be dialects, but in their present-day function they are languages, standardized for use by a particular nation. This certainly is true of Czech and Slovak, of Bulgarian and Macedonian, of Ukrainian and Russian, and, to some extent, of more distantly related languages such as Spanish and Italian or Czech and Polish.

We explore the case of the multicultural nation of the Philippines, where 186 languages exist. These are languages and not dialects, as linguists would technically classify them (McFarland 2008: 131). Eighty-five per cent of the 94 million $^{5}$ inhabitants of the archipelago account for the eight major language groups (Tagalog, Cebuano ${ }^{6}$, Ilokano, Hiligaynon, Bikol, Samar-Leyte, Kapampangan, and Pangasinan) followed by 2 large groups in Mindanao (Maranao and Maguindanao) (McFarland 2008: 132). We suggest that a significant obstacle towards building a collective "national identity" is the controversial status of the national language "Filipino", which is essentially the same as the Tagalog language in the linguistic sense (Tupas 2014). Though the 1987 Philippine Constitution clearly states that "as [the national language] evolves, it shall be further developed and enriched on the basis of existing Philippine and other languages,"7 this anticipated development has hardly been accomplished. This is compounded by the fact that Spanish and American colonial authorities have historically privileged Tagalog culture, and the seat of government has always been in the Tagalog capital of Manila. In Philippine history there has been conscious resistance from other regional groups against the "Filipino" language because of its Tagalog base and its unsuccessful assimilation of other Philippine languages.

This linguistic situation has resulted in an imbalance in the research on "Filipino" ethical concepts. For example, the research on "Filipino values" which began in the 1960s, and the various movements such as "Filipino psychology" which followed it, were all Tagalog language-based, while similar academic work in other languages were not produced. Later work on "Filipino ethics" was also limited to Tagalog words and concepts (cf. De Castro 1995a, 1995b). Though it would be natural to begin with such concepts because of the majority status of the Tagalogspeaking population, ${ }^{8}$ it may lead to a certain misrepresentation. The label "Filipino" gives the impression of natural inclusivity when in fact it is prejudiced to only one culture. Given the cultural diversity in the Philippines, the title "Filipino ethics" should take into account the ethical concepts of other regions and should inspire more inclusive democratic dialogue. 
In this paper we differentiate between three possible approaches to transcultural ethical research and dialogue in the Philippine context under the headings of (1) Pilipino ethics, (2) Filipino ethics and (3) Philippine ethics. The first (Pilipino ethics) is explicitly Tagalog-culture based (the adjective "Pilipino" is a Tagalog word). The second (Filipino ethics) is Tagalog-based but with an opt-in possibility for other cultures (the adjective "Filipino" is an English word with a general scope, but the connotation is tied to the "Filipino" language which is, as we have mentioned, Tagalog-based and has yet to be expanded by including other Philippine languages). This second approach is the current status quo. The third option (Philippine ethics) is an inclusive and open-ended approach conducted multilingually and reverting to English only as an instrument of mutual explication (the adjective "Philippine" is an English word that does not connote any privileged ethnic group, rather it is used in a general territorial sense). By "instrument of mutual explication" we mean that English should merely serve as a tentative bridge in order for two different Philippine languages to find the closest counterparts to their ethical concepts or to overcome certain misunderstandings. The use of English will ideally diminish as multilingual communication progresses. In this paper we will explain the disadvantages of the first two approaches and show the advantages of the third approach. To show the feasibility of this third approach, we will also draw inspiration from the linguistic phenomena of Scandinavian semicommunication, specifically the Scandinavian practice of using one's own distinct languages (Norwegian, Swedish, Danish) when conversing with each other within the region.

\section{Cultural diversity in the Philippines: Historical reflections}

The Philippines is an archipelago composed of 7,107 islands, around a thousand of which are inhabited (Philippine Statistics Authority 2010). It is divided into three major regions: Luzon, Visayas, and Mindanao. The Philippines' geographical structure has resulted in a great diversity of ethnic and linguistic groups. One recent report lists as many as 186 Philippine languages (Lewis 2015). Though each group has its own set of unique cultural traditions and practices, one can reasonably generalize certain features common to all of them prior to the arrival of Islam in the $14^{\text {th }}$ century or the Spaniards in the $16^{\text {th }}$ century, namely their tribal social structure with a heavy emphasis on kinship relations, and their animist religion (Scott 1994). What such societies must have looked like prior to foreign influence can be gleaned from the history of certain Philippine tribes that managed to resist foreign influence well into the $20^{\text {th }}$ century, such as those living in the Cordillera Mountains (Barton $1919,1949)$ or by comparisons with similar tribal societies among the Melanesians (Malinowski 1932). This tribal-animist base may be considered the first level of multiculturalism upon which foreign influences eventually built upon.

The second level of multiculturalism involves the introduction of foreign traditions that transformed indigenous cultures. We prefer to use the word "tradition" for this second level to indicate that the immigration of foreign populations was minimal, rather, once foreign ideas were established, native people themselves often spread, modified, and propagated them. This was most prevalent with the arrival of the Islamic tradition in the $14^{\text {th }}$ century (Majul 1999) and the Spanish tradition in the $16^{\text {th }}$ century (Schumacher 2009). Alasdair MacIntyre calls a 
tradition "an argument extended through time in which certain fundamental agreements are defined and redefined..." (MacIntyre 1988: 12). This entails building over the traditional thinking of previous generations with a more or less continuous understanding of what certain concepts and ideas mean. Unpredictable transformations are liable to take place when a foreign tradition is grafted onto a completely different culture, such as the tribal-animist cultures that were found in the archipelago. The indigenous population would naturally interpret new ideas through the lens of their own worldview. There were occasions for mistranslation (Rafael 1993), which one can clearly see in the syncretization of Spanish Catholicism with animist practices (Bulatao 1992). But there were also transformations of certain moral and ethical concepts coming either from the indigenous culture or from the foreign tradition. For example, the Tagalog utang-na-loób (debt of gratitude, debt of will) reciprocity, which was likely very similar to the obligatory gift-giving practices of the Melanesians (cf. Mauss 1966; Kaut 1961; Holnsteiner 1973) took on newer, more altruistic dimensions after 300 years of Spanish colonization (cf. De Castro 1998). Because the Spaniards chose not to impose the Spanish language on the indigenous population but instead to translate into the vernacular for their missionary work, certain indigenous concepts-many of them of an ethical or religious nature-were modified and expanded in meaning. Such syncretization would of course have varied in degree from group to group and from region to region, though as we have said, so far only Tagalog ethical concepts have been given significant attention in ethics research.

Another complicating factor in the cultural situation of the Philippines was the arrival of the Americans in the $20^{\text {th }}$ century, which built over the two levels of multiculturalism already mentioned. The Americans obtained the Philippines from the Spaniards in 1898 through the Treaty of Paris. The American tradition thrust the Philippines from its medieval world into Western modernity. It introduced democratic government and many educational reforms. "It was in the American 'gaze' that much of what subjectively constitutes nation for Filipinos was formed" (Mojares 2006: 12). However, given the tribal-animist base cultures, and the Islamic and Spanish foreign traditions, it is not surprising that American modernity was interpreted in ways that were congruent with the preceding cultural and traditional influences. Whereas American history benefitted from a series of political and intellectual revolutions in Europe (the Protestant Reformation, the Enlightenment, the French Revolution, etc.) that allowed the framing of ideas for the American Constitution and the conception of democracy, the Philippines did not share in this particular history.

\section{'Filipino' and the quest for a national language}

During Spanish colonization the official language was Spanish but this was not generally taught to the indigenous population since the missionaries, adopting a different strategy from the one employed in South America, chose to utilize the indigenous languages. "After more than 300 years of Spanish rule, less than 5 percent of Filipinos spoke Spanish" (Hardacker 2012: 12). Though this may have had its disadvantages as an educational policy, one cultural advantage was that it preserved words and concepts in indigenous languages that would otherwise have 
been forgotten if a widespread switch to Spanish had been made. Many of these indigenous words and concepts constitute the material for local intercultural dialogue on ethics in the Philippines.

When the Americans arrived, their colonial strategy included establishing a highly effective public school system and teaching the English language to the indigenous population (Hunt 1988). The arrival of 600 American teachers on the transport ship USAT Thomas in August 1901 signalled a new era of education in the Philippines, one that ensured that English would become a national language of the country even as Spanish would eventually be forgotten.

The 1935 Philippine Constitution, formed under American oversight, indicated English and Spanish as official languages but also made the provision to "take steps toward the development and adoption of a common national language based on one of the existing native languages." "The National Language Institute (NLI) was established in 1936 and tasked with "a study of the Philippine dialects in general for the purpose of evolving and adopting a common national language based on one of the existing native tongues." ${ }^{\prime 10}$ In 1937 the NLI chose Tagalog as the base language for the national language, a decision that then President Manuel Quezon proclaimed on December 30, 1937. ${ }^{11}$ For 21 years this national language had no name and was simply called Wikang Pambansa ("national language"). In 1959, Jose Romero, the Secretary of Education, renamed it "Pilipino". During this time in the 1960s there were already objections by various congressmen and non-Tagalog groups against the propagation of Pilipino because of a tendency towards Tagalog purism (Rubrico, 1998). Nevertheless Pilipino was made a medium of instruction in elementary schools across the country. ${ }^{12}$ The 1973 Philippine Constitution recognized Pilipino as an official language alongside English and also mandated "steps towards the development and formal adoption of a common national language to be known as Filipino." 13 Therefore the switch was made from Pilipino to Filipino. This was finalized in the 1987 Constitution, which states: "The national language of the Philippines is Filipino. As it evolves, it shall be further developed and enriched on the basis of existing Philippine and other languages."14 Though there is some progress in this enrichment as represented in the U.P. Diksiyonaryong Filipino (University of the Philippines Filipino Dictionary) which takes into account Filipino words from English and other Philippine languages (Almario 2010), such "enrichment", if it can even be called this, has been more passive than active. In practical terms, Filipino is still Tagalog. This has resulted in a cultural one-sidedness in the exploration of "Filipino concepts," especially ethical concepts.

\section{Filipino values and Filipino ethics}

The beginning of scholarly interest in Filipino values can be traced to Frank Lynch's famous article "Social Acceptance" (Lynch 1961). Lynch was an American Jesuit anthropologist who worked at the Ateneo de Manila University. He was famous for positing "smooth interpersonal relations" as the prime value of Filipino culture. He and his colleagues also dealt with other Filipino (i.e. Tagalog) concepts such as "hiya" (shame, sense of propriety) (Bulatao 1964) and "utang-na-loób" (debt of gratitude, debt of will) (Holnsteiner 1973), which would be elaborated on by future scholars. His work and those of his colleagues were instrumental in establishing the field of research on Filipino values. 
This initial foundation was both challenged and expanded by the Filipino psychology (Sikolohiyang Pilipino) movement established by Virgilio Enriquez in the 1970s (Pe-Pua \& Protacio-Marcelino 2000). Instead of the "smooth interpersonal relations" of Lynch, Enriquez posited kapwa (other person) as the "core value" of Filipino culture (Enriquez 1978). The Filipino psychology movement further identified and catalogued a set of Filipino concepts as "Filipino values" (Clemente 2008: 3). Filipino philosophers also expanded this research from psychological "values theory" to the field of philosophical ethics, such as in the pioneering work of Mercado (1979) and de Castro (De Castro 1995a, 1995b). More recently Reyes has argued that many Filipino concepts more consistently form a "virtue ethics" rather than a "value system" (Reyes 2013, 2015).

However, Tagalog concepts have clearly been prioritized in this field of studies. There is a general impression that phrases such as "Filipino values", "Filipino psychology" and "Filipino ethics" automatically represent the Philippines as a whole (this is one of the unfortunate ambiguities of the adjective "Filipino"), when in fact they only represent the majority Tagalog culture. It is more accurate to say that the current research on Filipino ethics has so far only represented one type of Filipino ethics among many that are still unexplored.

Very little research has been done on ethical concepts from other Philippine languages and cultures, even though there were already hints made by early pioneers that intercultural ethical dialogue could take place because of similarities between concepts such as the Tagalog loób (literally "inside" or "will/desire" but no English word seems to accurately translate this word or other similar Philippine words), the Ilokano nakem, the Bikolano boot and the Bisayan buot, all of which pertain to the person's will and holistic self (cf. Mercado 1976: 54). The concept of loób is particularly crucial in Filipino (Tagalog) ethics, because it is the subject of many of the virtue words in the form X-loób, such as the compounds kagandahanglóob (beautiful-willed) and masamang-loób (bad-willed). These virtue words, as Reyes suggests, evince the basic structure of a Filipino virtue ethics (Reyes 2013, 2015). Mercado himself recommended "that the counterparts of loób in other Philippine languages be studied in order to have a true Filipino view" (Mercado 1994: 37). Recent publications in Bikol philosophy (Tria 2006; Loquias 2014) mirror the early publications in Filipino philosophy several decades ago. This is a promising development, but it also shows how long such projects were neglected compared to Filipino. Stimulating philosophical and ethical research in other cultures and languages requires challenging the status quo that narrowly defines "Filipino ethics" on the basis of "Tagalog ethics." Furthermore, ethical dialogue can be pursued through the common ground of similar concepts. This is where our proposal of "Philippine ethics", which at first might have seemed only a matter of terminology, becomes especially relevant.

\section{Inclusive collective identity building in the Philippines: insights from the phenomena of Scandinavian semicommunication}

Multicultural societies are prone to deep conflicts that require inclusive ways of resolution (Alvarez 2014). Deep conflicts arise regarding the principles and manner by which we should settle our disagreements about our moral and ethical beliefs. It 
is one thing to resolve our disagreements about our moral beliefs. That is the usual kind of conflict. It is another thing to resolve our differences about the manner by which we should settle our disagreements. Deep conflict underlies this second kind of disagreement. Our moral principles are determined by our comprehensive views of the world that we inherit from our respective cultural traditions. An approach to conflict resolution that is inclusive must take cultural differences seriously, if any public resolution of deep conflicts is to be legitimately adopted by all members of the multicultural collective. There is no room for hegemonic imposition of particular cultural traditions on others, including language, even if good pragmatic reasons exist to do so. Imposing a dominant cultural tradition, even if it succeeds, makes the outcome prone to resentment from the subordinate groups who may question its legitimacy.

Three important reasons to be more inclusive in the use of other languages (versus allowing one hegemonic language to dominate the rest) in building collective culture identity in multicultural societies are to:

1. Optimize learning. Allowing speakers to use their own mother tongue (or first language) has been proven to optimize learning among primary school learners (Gonzalez 1981, 1998; Nolasco 2008; Tupas 2014; Tupas \& Lorente 2014). Education researchers in the late 1960s already recognized the importance of this approach, even citing Scandinavian semicommunication as a source of ideas on how to implement multilingualism in primary schools in North America at that time (Kloss 1969). ${ }^{15}$

1. Allow full expression. The use of one's mother tongue facilitates the full expression of ideas that allow them to flourish and be appreciated by others.

2. Promote recognition and authenticity. Inclusiveness promotes freedom and non-domination in a deep way. If language can, in some way, influence how we view the world, ${ }^{16}$ then imposing a language on speakers can impede their ability to conceptualize and evaluate their experiences in relating with others. Allowing speakers to use their mother tongue may promote a more authentic expression of thoughts that conceptualize their experiences. We owe it to each other to mutually give recognition to each of our own distinct identities if we are to legitimately build a common authentic collective identity (Taylor 1994: 65-72).

The persistence and success of the linguistic phenomena of semicommunication in Scandinavia offer insight on ways the Philippines could proceed with its national identity building project, especially the unfinished project of creating a lingua franca that will be accepted and used by all different language speakers without grudges or resentment. Tagalog speakers need not continue to be privileged, and implementing a kind of affirmative action towards marginalized language cultures could help compensate for decades of linguistic domination. Non-Tagalog speakers do not have to be subjected to Tagalized communication in order to identify with the Philippine national collective. Cebuanos, Ilokanos, and Ilonggos are equally Filipino even if they do not speak a word of Tagalog and vice versa. Although the Scandinavian situation is different in scope since the three languages of Norwegian, Swedish and Danish are spoken by three different nations, their regional collective identification as Scandinavians offers a parallel from which other multilingual and multicultural societies, e.g. the Philippines, could learn. One possibility, as in 
Scandinavian semicommunication, is for different language speakers in the Philippines to try to communicate with each other in their own mother tongue. It may be difficult at first, and it does not mean they will understand each other $100 \%$. The three different Scandinavian language speakers do not understand each other $100 \%$ either but they do understand each other enough for the practice of semicommunication to persist (Gooskens 2006). Speakers of any of the three languages are thus able to express themselves fully and convey concepts formed in their own languages with experimental persistence. In this same manner, phonological and lexical barriers fall away when different Philippine language speakers patiently try to communicate in their own mother tongues, both in spoken and written forms. ${ }^{17}$ In cases where the linguistic distance between two Philippine languages becomes too wide for comprehension, there is always the possibility of tentatively resorting to English, but with the hope that the continued practice of multilingual communication will gradually diminish the need for English.

A possible research program for "Philippine ethics" is to implement Mercado's suggestion of a study of the counterparts for the Tagalog concept loób in other Philippine languages and cultures (Mercado 1994: 37). This would entail inviting proficient native speakers of other Philippine languages to explain their own version of the concept, without requiring them to translate their ideas into Filipino/Tagalog or limiting themselves to how this concept has been defined in Filipino/Tagalog literature. Nuances in the use of the concept will be brought to the surface, enabling a tentative table of similarities and differences to be constructed. One point that is particularly inspired by the Scandinavian semicommunication model is the requirement that the direct theorization and explanation of these concepts also be conducted in the corresponding language before it is expressed in English, if at all. English then would serve only as a last resort in facilitating the inter-cultural dialogue.

Such a research project would require sufficient resources and correspondents, preferably from different levels of society. It would also require key participants to learn the rudiments of the other represented Philippine languages, to obtain at least some degree of mutual comprehension. Though such a project would require much time and effort, it could yield a more synoptic approach to research in Philippine ethics than has been achieved to date. It would represent an advance over the Filipino/Tagalog-centric research that has been done so far, especially in how it avoids direct and immediate theorization in English.

One hypothesis is that the project would reveal "family resemblances,"-to use a term from Wittgenstein-between the different languages and their ethical concepts, "a complicated network of similarities overlapping and criss-crossing" (Wittgenstein 1958: 32). Resemblances and commonalities can be used as the groundwork for inclusive collective identity building. Because the focus is on key ethical concepts and not just any arbitrary concepts, further dialogue can be pursued in terms of multicultural Philippine ideas on morality and human flourishing. Such ideas can be used to influence the teaching of ethics and values in Philippine schools and the cultural sensitivity of government policy-making, for example.

To conclude, collective identity building can be pursued through the practice of multilingual communication. This multilingual communication in turn may be most productively deployed in the sphere of ethical concepts. The inspiration of 
Scandinavian semicommunication can significantly affect the middle linguistic link between collective identity building and ethical concepts in the Philippine context. It offers a means of challenging the status quo of Filipino/Tagalog dominance and correcting the marginalization of other Philippine languages and ethical concepts in the development of national identity. The prospect of a linguistically diverse and inclusive ethics research programme is one that scholars should seriously consider if they are committed to solving the tensions inherent in such a multicultural society as the Philippines.

\section{Acknowledgments}

We would like to thank two anonymous reviewers for carefully reading our paper and for their incisive and critical comments that helped us further clarify our arguments and improve our manner of presentation. Whatever shortcomings remain are our sole responsibility.

\section{Notes}

${ }^{1}$ ten Thije (2013) and Rehbein, ten Thije, \& Verschik (2012) list other ways to refer to this same linguistic phenomenon as

a. 'intelligibility of closely related languages' (Gooskens 2006; Wolff 1959)

b. 'semicommunication' (Haugen 1966; Zeevaert 2007)

c. 'the Swiss model' (Lüdi 2007)

d. 'inter-comprehension' (Conti 2008 as cited in ten Thije 2013)

e. 'receptive multilingualism' (Braunmüller 2007; Zeevaert \& Thije 2007)

We selected Scandinavian semicommuncation as a point of reference as it is widely referred to as such. A further step is Lingua Receptiva where speakers are not confined to using their mother tongue but may use other languages that may be effective in communication, such as a native speaker of Norwegian speaking Norwegian and a native speaker of Portuguese speaking English (ten Thije 2013: 137).

2 The Philippines is a multicultural society in the sense that this "super-nation" is composed of distinct ethnic groups that were separate and autonomous "nations" before the arrival of Europeans in 1521 (cf. Quilop 2006: 4-5). The way these different ethnic groups combined into one nation is different from the way immigrant countries (such as Canada, U.S.A, and others) became multicultural, since in the Philippines nationhood was imposed mainly through colonial conquest. Both kinds of multicultural countries share many challenges in consolidating one nation and one identity, such as linguistic and cultural barriers. We intend to focus on the similarity of the struggle with ethnic differences that multi-nation countries and immigrant countries face, without denying that there could be more complex dynamics involved that limit the comparison between the two types of multiculturalism. 
${ }^{3}$ The apparent dominance of the Tagalog language, especially in the national and official language policies of the Philippines, has been evident in the history of the country (Gonzalez 1981, 1991, 1998, 2001; Villacorta 1991). The prominent late linguist Gonzalez explained that the historical circumstances allowed Tagalog to be chosen from among other existing languages to become the basis of the national language in-the-making, but he added that there was strong and continuing objection to this dominance by leading politicians from other regions, especially Cebu (Gonzalez 1991: 114-125). The National Language Act of 1936 allowed the then National Language Institute to choose Tagalog as the basis of the national language (Gonzalez 1991: 122), which the Cebuano Bisayans did not accept (Gonzalez 1998: 487). The perceived purism of the Institute was challenged and lost in the Supreme Court by Bisayan Congressman Inocencio Ferrer in the 1960s, leading to the so-called 'language wars' of that time (Gonzalez 1991: 122; Gonzalez 1998: 487). Calling the dominance 'Tagalog imperialism' or fourth colonization (after the Spanish, American and Japanese) and comparing the resistance to it with Basque nationalist Salvador de Madriaga's protest to Franco's domination show the intensity of the resistance (Gonzales 1991: 124-125). The Constitutional Convention of 1971-1973 gave way to a compromise solution of adopting a universalist approach to future national language policy, during which 'Filipino' was used to name the future national language instead of the term 'Pilipino' used by the National Language Institute earlier (Gonzalez 1998: 488). No national language was adopted at that time since the commissioners could not agree. The Constitutional Commission of 1986 had heated debates on the language issue (for example between Bisayan Hilario Davide and Tagalog Wilfredo Villacorta) (Gonzales 1991: 123). The 1987 Constitution later stated, however, that Filipino is an existing language that is to be enriched as a national language (Gonzalez 1998: 488). The fact remains that the Filipino recognized by the 1987 Constitution as national language is still basically Tagalog-based.

${ }^{4}$ The Americans granted independence on July 4, 1946. This date was recognized as the date of Philippine independence until 1964, when President Diosdado Macapagal, urged by historians and nationalists, signed into law Republic Act No. 4166, which changed Independence Day to July 12, 1898 in recognition of the earlier declaration of independence by General Emilio Aguinaldo from Spain. However the 1946 date of independence is more significant in this context insofar as it serves as a marker for the evolution of the national language policy in the country vis-à-vis American influence.

${ }^{5}$ This is the mid-year population reported in 2010 (National Statistics Office 2014). The official published figure based on the 2010 census is 92.34 million (see http://web0.psa.gov.ph/).

${ }^{6}$ In the 1980s, it was reported by (Gonzalez 1981) that Cebuano, at the time of the 1980 census, is the language spoken by the most number of residents of the Philippines. The 1995 census reported Tagalog as the language spoken by most residents of the Philippines at that time, but Gonzalez doubts the accuracy of that report since:

... [it shows] the number of speakers per language at least as these language names were used by the census enumerators and respondents (who were not 
linguists). The census figures are based on a study of households and reflect only the language used in the household; no provision has been made since the 1990 census to enumerate speakers of Tagalog (Filipino) as a second language and of speakers of English as a second language (Gonzalez 1998: 498).

${ }^{7}$ The 1987 Philippine Constitution, Article XIV, Section 6.

${ }^{8}$ The majority status of Tagalog speakers was disputed in the 1980s and even in the 1990s on grounds of census methodology. A majority of native speakers of other languages may be able to understand Tagalog Filipino but it is not their mother tongue (Gonzalez, 1998).

9 The 1935 Philippine Constitution, Article XIII, Section 3.

${ }^{10}$ Commonwealth Act No. 184, "An Act to Establish a National Language Institute and Define its Powers and Duties," Section 5.

${ }^{11}$ Executive Order No. 134, "Proclaiming the National Language of the Philippines Based on the 'Tagalog' Language."

12 The mandate to teach the national language in all elementary schools began as early as 1943. However a more pronounced Pilipino-English bilingual education was enforced in 1974 following the 1973 Philippine Constitution (Espiritu 2015). This bilingual education, which generally neglected other vernacular languages of the Philippines, was continuously revised and followed until 2013, when the Mother Tongue-Based Multilingual Education (MTB MLE) was introduced as part of the K12 program (Department of Education 2012). This allows the mother tongue of the students to be the medium of instruction from kindergarten until Grade 3. It must be noted however that the goal of this phase is to aid the linguistic proficiency of the student in Filipino and English in later grades.

${ }^{13}$ The 1973 Philippine Constitution, Article XV, Section 3.

${ }^{14}$ The 1987 Philippine Constitution, Article XIV, Section 6.

${ }^{15}$ With reference to Scandinavian semicommunication, Kloss (1969) has suggested at that time that:

It would seem unnecessary to teach Danish to a Norwegian in the same fashion as one would teach English or French. The fundamental proposition involved here is that it may be sufficient to awaken, or simply strengthen a dormant knowledge of the second language so that e.g. a Czech and a Slovak could communicate by each speaking his own language. Reinforcement of the other language may take place by exchanging letters, or listening to the other man's voice on the radio or the tape recorder.

In the Scandinavian countries where we have much inherent bilingualism among the speakers of Swedish, Danish and Norwegian (Bokmål) much spadework has been done in the schools along this line. It would be a worthwhile task to have some Scandinavian educators report of their experiences so that other nations might benefit from them and apply them to their own particular situations. Much that is pertinent will be found in Einar Haugen's paper on "Semicommunication" (see Haugen 1966; Kloss 1969). 
16 The well-known theory attributed to Sapir and Whorf, called the Sapir-Whorf hypothesis, claims that language determines the way we comprehend the world. Even if the Sapir-Whorf hypothesis has not been shown as absolute in determining cognition, there are indications that language may, to some extent, "induce nonlinguistic cognitive differences" (Kay \& Kempton 1984: 77). To a limited extent, there could be some truth to the old belief that

We dissect nature along lines laid down by our native languages. The categories and types that we isolate from the world of phenomena we do not find there...on the contrary, the world is presented in a kaleidoscopic flux of impressions which has to be organized by our minds-and this means largely by the linguistic systems in our minds (Whorf 1956[1940]: 212).

17 There is, however, a need to further investigate the relative distances between these languages in order to assess how much effort speakers would exert to try to be understood. Are these differences greater or less than the differences between Scandinavian languages?

\section{References}

Almario, V. S. (2010). UP Diksiyonaryong Filipino, 2nd Ed. Quezon City: UP Sentro ng Wikang Filipino.

Alvarez, A. A. (2014). The Place of Culture-based Reasons in Public Debates. Human Affairs, 24 (2), 232-247. http://dx.doi.org/10.2478/s13374-014-0222-0

Barton, R. F. (1919). Ifugao law. University of California Publications in American Archaeology and Ethnology, 15(1), 1-186.

Barton, R. F. (1949). The Kalingas: Their Institutions and Custom Law. Chicago: University of Chicago Press.

Braunmüller, K. (2007). Receptive multilingualism in Northern Europe in the Middle Ages: A description of a scenario. In J. D. t. Thije \& L. Zeevaert (Eds.), Receptive multilingualism: linguistic analyses, language policies and didactic concepts (pp. 25-47). Amsterdam: J. Benjamins Pub. Co. http://dx.doi.org/10.1075/hsm.6.04bra

Bulatao, J. C. (1964). Hiya. Philippine Studies, 12(3), 424-438.

Bulatao, J. C. (1992). When Roman Theology Meets an Animistic Culture. In J. C. Bulatao (Ed.), Phenomena and their interpretation: Landmark essays, 19571989. Manila: Ateneo University Press.

Clemente, J. A. e. a. (2008). Revisiting the Kapwa Theory: Applying Alternative Methodologies and Gaining New Insights. Philippine Journal of Psychology, 41(2), 1-32.

Conti, V., \& Grin, F. (2008). S'entendre entre langues voisines: vers l'intercompréhension [Understanding between closely related languages: towards intercomprehension]. Chêne-Bourg: Georg. 
De Castro, L. (1995a). Ang Utang na Loob Bilang Konsepto ng Etika. Quezon City: CSSP Publications.

De Castro, L. (1995b). Etika at Pilosopiya sa Kontekstong Pilipino. Quezon City: University of the Philippines.

De Castro, L. (1998). Debts of Good Will and Interpersonal Justice. Retrieved June 6, 2015, from https://www.bu.edu/wcp/Papers/Asia/AsiaDeCa.htm

Department of Education. (2012). Guidelines on the Implementation of the Mother Tongue-Based Multilingual Education (MTB-MLE). Retrieved September 1, 2015, from http://www.deped.gov.ph/sites/default/files/order/2012/DO_s2012_16.pdf

Enriquez, V. (1978). Kapwa: A Core Concept in Filipino Social Psychology. Philippine Social Sciences and Humanities Review, 42(1-4), 100-108.

Espiritu, C. (2015). Filipino Language in the Curriculum. Retrieved September 1, 2015, from http://ncca.gov.ph/subcommissions/subcommission-on-culturaldisseminationscd/language-and-translation/filipino-language-in-thecurriculum/

Gonzalez, A. (1981). Language Policy and Language-in-Education Policy in the Philippines. Annual Review of Applied Linguistics, 2, 48-59. http://dx.doi.org /10.1017/S0267190500000246

Gonzalez, A. (1991). Cebuano and Tagalog: Ethnic rivalry redivivus. In J. R. Dow (Ed.), Language and Ethnicity (pp. 111-130): John Benjamins Publishing. http://dx.doi.org/10.1075/z.fishfest2.08gon

Gonzalez, A. (1998). The Language Planning Situation in the Philippines. Journal of Multilingual and Multicultural Development, 19(5), 487-525. http://dx.doi.org /10.1080/01434639808666365

Gonzalez, A. B., \& Villacorta, W. V. (2001). The Language Provision of the 1987 Constitution of the Republic of the Philippines: Linguistic Society of the Philippines.

Gooskens, C. (2006). Linguistic and extra-linguistic predictors of InterScandinavian intelligibility. Linguistics in the Netherlands, 23(1), 101-113. http://dx.doi.org/10.1075/avt.23.12goo

Hardacker, E. (2012). The Impact of Spain's 1863 Educational Decree on the Spread of Philippine Public Schools and Language Acquisition. European Education, 44(4), 8-30. http://dx.doi.org/10.2753/EUE1056-4934440401

Haugen, E. (1966). Semicommunication: The Language Gap in Scandinavia. Sociological Inquiry, 36(2), 280-297. http://dx.doi.org/10.1111/j.1475-682X. 1966.tb00630.x

Holnsteiner, M. (1973). Reciprocity in the Lowland Philippines. In F. Lynch \& A. de Guzman II (Eds.), Four Readings on Philippine Values (pp. 69-92). Quezon City: Ateneo de Manila University Press.

Hunt, C. (1988). Education and Economic Development in the Early American Period in the Philippines. Philippine Studies, 36(3), 352-364. 
Kaut, C. (1961). Utang Na Loob - a System of Contractual Obligation among Tagalogs. Southwestern Journal of Anthropology, 17(3), 256-272.

Kay, P., \& Kempton, W. (1984). What Is the Sapir-Whorf Hypothesis? American Anthropologist, 86(1), 65-79. http://dx.doi.org/10.1525/aa.1984.86.1.02a00050

Kloss, H. (1969). Research Possibilities on Group Bilingualism: A Report. 1-96. Retrieved from http://files.eric.ed.gov/fulltext/ED037728.pdf

Lewis, M., Simons, G. and Fennig, C. (2015). Ethnologue: Languages of the World, Eighteenth edition Retrieved from http://www.ethnologue.com/country/PH

Loquias, V. J. (2014). A Linguistic Exploration of the Bikol Concept of Tood: Towards a Philosophical Framework for Education. Filocracia, 1(1), 156-166.

Lüdi, G. (2007). The Swiss model of plurilingual communication. In J. D. t. Thije \& L. Zeevaert (Eds.), Receptive multilingualism: linguistic analyses, language policies and didactic concepts (pp. 159-178). Amsterdam: J. Benjamins Pub. Co. http://dx.doi.org/10.1075/hsm.6.10lud

Lynch, F. (1961). Social Acceptance. In F. Lynch (Ed.), Four Readings on Philippine Values (pp. 1-21). Quezon City: Ateneo de Manila University Press.

MacIntyre, A. (1988). Whose Justice? Which Rationality? Notre Dame: University of Notre Dame.

Majul, C. A. (1999). Muslims in the Philippines. Quezon City: University of the Philippines.

Malinowski, B. (1932). Argonauts of the Western Pacific: An Account of Native Enterprise and Adventure in the Archipelagoes of Melanesian New Guinea. London: George Routledge \& Sons, Ltd.

Mauss, M. (1966). The Gift: Forms and Functions of Exchange in Archaic Societies (I. Cunnison, Trans.). London: Cohen \& West Ltd.

McFarland, C. D. (2008). Linguistic diversity and English in the Philippines. In M. L. S. Bautista \& K. Bolton (Eds.), Philippine English: Linguistic and Literary (Vol. 2008, pp. 131-156). Hong Kong: HKU Press. http://dx.doi.org /10.5790/hongkong/9789622099470.003.0008

Mercado, L. (1976). Elements of Filipino Philosophy. Tacloban City: Divine Word.

Mercado, L. (1979). Elements of Filipino Ethics. Tacloban City: Divine Word.

Mercado, L. (1994). The Filipino Mind. Washington D.C.: The Council for Research in Values and Philosophy.

Mojares, R. (2006). The Formation of Filipino Nationality Under U.S. Colonial Rule. Philippine Quarterly of Culture and Society, 34(1), 11-32.

National Statistics Office. (2014). The Philippines in Figures 2014. Retrieved May 30, 2015, from http://census.gov.ph/sites/default/files/2014\%20PIF.pdf

Nolasco, R. M. (2008). The prospects of multilingual education and literacy in the Philippines. The paradox of Philippine education and education reform: Social science perspectives. Manila: Philippine Social Science Council. 
Pe-Pua, R., \& Protacio-Marcelino, E. (2000). Sikolohiyang Pilipino (Filipino Psychology): A Legacy of Virgilio G. Enriquez. Asian Journal of Social Psychology, 3(1), 49-71. http://dx.doi.org/10.1111/1467-839X.00054

Philippine Statistics Authority. (2010). Geography. Retrieved May 30, 2015, from http://www.nscb.gov.ph/view/geography.asp

Quilop, R. (2006). Nation-State Formation in the Philippines. In T. Tadem \& N. Morada (Eds.), Philippine Politics and Governance: An Introduction (pp. 1-12). Quezon City: University of the Philippines.

Rafael, V. (1993). Contracting Colonialism: Translation and Christian Conversion in Tagalog Society under Early Spanish Rule. Durham and London: Duke University Press.

Rehbein, J., ten Thije, J. D., \& Verschik, A. (2012). Lingua receptiva (LaRa) Remarks on the quintessence of receptive multilingualism. International Journal of Bilingualism, 16(3), 248-264. http://dx.doi.org/10.1177/ 1367006911426466

Reyes, J. (2013). Loob at Kapwa: Mga Unang Hakbang Patungo Sa Isang PilipinongBirtud-Etika Gamit Si Sto. Tomas de Aquino. Asian Perspectives in the Arts and Humanities, 3(2), 1-26. http://dx.doi.org/10.13185/AP2013.03202

Reyes, J. (2015). Loób and Kapwa: An Introduction to a Filipino Virtue Ethics. Asian Philosophy, 25(2), 148-171. http://dx.doi.org/10.1080/09552367.2015 .1043173

Rubrico, J. G. (1998). The Metamorphosis of Filipino as National Language. Retrieved May 8, 2015, from http://www.languagelinks.org/onlinepapers/ fil_met2.html

Schumacher, J. (2009). Growth and Decline: Essays on Philippine Church History. Quezon City: Ateneo de Manila University Press.

Scott, W. H. (1994). Barangay: Sixteenth-century Philippine culture and society: Ateneo de Manila University Press.

Taylor, C. (1994). The politics of recognition. In A. Gutman (Ed.), Multiculturalism: Examining the politics of recognition (pp. 25-73). Princeton: Princeton University Press.

ten Thije, J. D. (2013). Lingua Receptiva (LaRa). International Journal of Multilingualism, 10(2), 137-139. http://dx.doi.org/10.1080/14790718.2013 .789519

ten Thije, J. D., \& Zeevaert, L. (2007). Receptive multilingualism: linguistic analyses, language policies and didactic concepts. Amsterdam: J. Benjamins Pub. Co. http://dx.doi.org/10.1075/hsm.6

Tria, W. J. (2006). Ako asin an Kapwa Ko: Pilosopiya nin Tawo. Naga City: Ateneo de Naga University Press.

Tupas, R. (2014). The politics of 'p' and ' $\mathrm{f}$ : a linguistic history of nation-building in the Philippines. Journal of Multilingual and Multicultural Development, 1-11. http://dx.doi.org/10.1080/01434632.2014.979831 
Tupas, R., \& Lorente, B. P. (2014). A 'New'Politics of Language in the Philippines: Bilingual Education and the New Challenge of the Mother Tongues. Language, Education and Nation-building: Assimilation and Shift in Southeast Asia, 165-180.

Villacorta, W. V. (1991). The politics of language in the Third World: toward theory building. International Journal of the Sociology of Language, 1991(88), 33. http://dx.doi.org/10.1515/ijsl.1991.88.33

Whorf, B. L. (1956[1940]). Science and Linguistics. In J. B. Carroll (Ed.), Language, Thought and Reality (pp. 207-219). Cambridge, Mass: M.I.T.

Wittgenstein, L. (1958). Philosophical Investigations (G. E. M. Anscombe, Trans. 2nd ed.). Oxford: Basil Blackwell.

Wolff, H. (1959). Intelligibility and Inter-Ethnic Attitudes. Anthropological Linguistics, 1(3), 34-41.

Zeevaert, L. (2007). Receptive multilingualism and inter-Scandinavian semicommunication. In J. D. t. Thije \& L. Zeevaert (Eds.), Receptive multilingualism: linguistic analyses, language policies and didactic concepts (pp. 103-135). Amsterdam: J. Benjamins Pub. Co. http://dx.doi.org/10.1075/hsm.6.08zee

Zeevaert, L., \& ten Thije, J. D. (2007). Introduction. In J. D. t. Thije \& L. Zeevaert (Eds.), Receptive multilingualism: linguistic analyses, language policies and didactic concepts (pp. 1-22). Amsterdam: J. Benjamins Pub. Co. http://dx.doi.org/10.1075/hsm.6.02zee 
